\title{
AGÊNCIAS REGULADORAS E AGÊNCIAS EXECUTIVAS
}

Distinção. Inexistência de legislação displinadora das agências executivas no estado do Rio de Janeiro. A autarquia ASEP-RJ é uma agência reguladora não qualificada como agência executiva. inaplicabilidade do Parágrafo Único do Art. 24 da Lei n 8.666/93

\section{AleXANDRE SANTOS DE ARAgão*}

I. A descentralização administrativa - II. A descentralização autárquica - III. As agências executivas - IV - As agências reguladoras - Conclusão

A Agência Reguladora de Serviços Públicos Concedidos do Estado do Rio de Janeiro - ASEP-RJ consulta esta Procuradoria a respeito da sua subsunção aos incisos I e II combinados com o Parágrafo Único do art. 24 da Lei $n^{\circ} 8.666 / 93$, com a redação dada pela Lei ${ }^{\circ} 9.648 / 98$, que dispõem:

Art. 24 - É dispensável a licitação:

I - para obras e serviços de engenharia de valor até $10 \%$ (dez por cento) do limite previsto na alínea "a" do inciso I do artigo anterior, desde que não se refiram a parcelas de uma mesma obra ou serviço ou ainda para obras e serviços da mesma natureza e no mesmo local que possam ser realizadas conjunta e concomitantemente;

II - para outros serviços e compras de valor até $10 \%$ (dez por cento) do limite previsto na alínea " $a$ " do inciso II do artigo anterior, e para alienações, nos casos previstos nesta Lei, desde que não se refiram a parcelas de um mesmo serviço, compra ou alienação de maior vulto que possa ser realizada de uma só vez;

* Mestre em Direito Público pela U.E.R.J. Professor contratado de Direito Administrativo e da disciplina eletiva "Agências Reguladoras" da Universidade do Estado do Rio de Janeiro - U.E.R.J. Procurador do Estado e Advogado no Rio de Janeiro. 


\section{III a XXIV - omissis.}

Parágrafo único. Os percentuais referidos nos incisos I e II deste artigo, serão $20 \%$ (vinte por cento) para compras, obras e serviços contratados por sociedade de economia mista e empresa pública, bem assim por autarquia e fundação qualificadas, na forma da lei, como Agências Executivas.

A Assessoria Jurídica da ASEP-RJ às fls. 03 e 15 e a Superintendência de Suprimentos da Secretaria de Estado de Administração e Reestruturação do Estado - SARE à fl. 13, entenderam que, sendo a ASEP-RJ uma autarquia, lhe é aplicável o parágrafo único acima transcrito, que aumenta o valor das dispensas de licitação para as autarquias qualificadas como agências executivas.

$\mathrm{O}$ trato do tema colocado pela consulta toca aos mais modernos mecanismos de descentralização material de setores da Administração Pública, apenas recentemente adotados no Direito Positivo Brasileiro, o que, somado à semelhança da nomenclatura utilizada, torna muito natural a confusão e as incertezas que sobre eles por vezes recaem.

Estes fatores fazem com que a questão deva ser tratada com bastante cautela e minúcia, mas sem misoneísmos, buscando, desta forma, traçar uma orientação segura e sem percalços para a Administração Pública Fluminense diante de institutos tão novos quanto relevantes.

Muito se tem falado na figura da "agência" como um instrumento de modernização da Administração Pública. O termo, no entanto, em si, é vazio de conteúdo, e a mera denominação de um órgão ou entidade como tal, sem que a medida venha acompanhada da disciplina jurídica que lhe assegure efetiva autonomia, nada significa.

Poder-se-ia dizer que a qualificação de um órgão como "agência", até por sua origem etimológica (do latim, agentia, direção, condução, incitação) denota a especialidade de suas funções e/ou a sua independência funcional. Não discordamos da assertiva, mas, mais importa as normas que venham a estabelecer as funções específicas e/ou a autonomia do órgão, do que a simples denominação.

Maria Sylvia Zanella di Pietro ${ }^{1}$ entende, em tom crítico, que "o vocábulo "agência" é um dos modismos introduzidos no direito brasileiro no movimento da globalização. Foi importado do direito norte-americano, onde tem sentido mais amplo, que abrange qualquer autoridade do Governo dos Estados Unidos, esteja ou não sujeita ao controle de outra agência, com exclusão do Congresso e dos Tribunais".

No Direito francês também é destacado o vazio existente no conceito de agência, que objetiva apenas reforçar a necessidade de eficiência através da flexibilização dos controles hierárquicos. O Mestre JEAN RIVERO, ${ }^{2}$ por exemplo, afirma que "a seguir a 1919 surge a preocupação de tornar mais flexíveis, por meio da personali-

1 In "Direito Administrativo", Ed. ATLAS, 11" ed., 1999, p. 385.

2 In "Direito Administrativo", Almedina, Coimbra, 1981, trad. Rogério Ehrhardt Soares, p. 529. 
zação, os métodos administrativos: os estabelecimentos criados nessa altura tomam muitas vezes o nome de "ofício", que, aliás, não tem qualquer significado jurídico, tal como o de "agência", em voga desde há alguns anos".

O que, destarte, a idéia de "agência" transmite é a necessidade em se obter maiores poderes e eficiência mediante a adoção de mecanismos de gestão administrativa não hierarquizada. "A terminologia ainda é muito nova, para permitir uma classificação das agências no direito brasileiro. Duas modalidades, no entanto, já se delineiam de forma um pouco mais precisa: as agências executivas e as agências reguladoras". 3

Feitas estas colocações, o deslinde da consulta pressupõe, (I) o entendimento da descentralização no Estado contemporâneo, (II) a definição do que vêm a ser as autarquias, (III) as agências executivas e (IV) as agências reguladoras, analisando-se, concomitantemente, as respectivas legislações, para, por fim, podermos afirmar se a ASEP-RJ caracteriza-se ou não como uma agência executiva, sendo-lhe, se for este o caso, aplicável o parágrafo único do art. 24 da Lei n 8.666/93.

\section{I- A descentralização administrativa}

As estruturas político-administrativas tradicionais, morosas e inspiradas por critérios preponderantemente políticos, se revelaram, em um movimento crescente a partir do advento da Primeira Grande Guerra, inadequadas para os desafios colocados ao Estado.

VITAL MOREIRA 4 observa que "na concepção tradicional a administração pública apresentava um perfil unitário, baseado nos serviços departamentais hierarquizados, na direcção governamental e na responsabilidade parlamentar do Governo pela actividade da administração. O modelo originário da administração pública do Estado constitucional era a "administração ministerial", isto é, a administração hierarquicamente organizada sob a égide de um Ministro responsável. (...) Hoje a "unidade da administração é uma ficção", sendo incontroversa a sua natureza "plurifórmica e pluricêntrica", (...) o que constitui "resultado natural da passagem do Estado burguês oitocentista, tipicamente monoclassista", voltado exclusivamente para a proteção dos interesses da burguesia então vitoriosa, para o Estado pluriclasse contemporâneo" (sufrágio universal, acesso democrático aos cargos da administração pública, desenvolvimento dos sindicatos, prestações estatais positivas etc.), "que necessariamente reflete na sua organização o incontornável e crescente pluralismo da organização social. (...) O pluralismo social e político provocou o pluralismo e a diferenciação organizatória da administração." De outra forma, o Estado não poderia desempenhar suas atribuições com a agilidade e eficiência necessárias". 5

3 Maria Sylvia Zanella Di Pietro, in ob. cit., p. 387.

4 In "Administração Autónoma e Associaçōes Públicas", Coimbra, 1997, pp. $31 / 5$ (grifos nossos).

5 Cf. Hughes, in "Some Aspects of Development of American Law", 1916, 39, New York State Bar Association Reports, 266, 269. 
A mera criação de órgãos internos. especializados. mas meramente auxiliares, isto é, sem qualquer autonomia, não atenderia às necessidades complexas e sempre urgentes da coletividade. ${ }^{6}$

A fórmula que. até o momento, mais obteve êxitos foi a descentralização administrativa através de órgãos ou entidades, geralmente especializados tecnicamente, dotados, em maior ou menor escala, de autonomia e que. atípicos em relação ao tradicional aparato administrativo hierarquizado, atuam com acentuado poder decisório.

Naturalmente que nenhum modelo administrativo é inteiramente descentralizado ou centralizado. A adoção completa daquele levaria à desintegração da organização administrativa, e. a deste, à sua inviabilização prática. ${ }^{7}$

Mas, qualquer que seja a extensão em que, concretamente, venha a ser adotada, "o valor da descentralização é amplamente reconhecido, seja no seio de uma única organização administrativa. seja com referência ao relacionamento entre múltiplas estruturas, que fazem parte de uma organização mais abrangente vista em sua totalidade". 8

Os estudiosos da ciência da administração, da ciência política e do direito costumam afirmar que o problema da transferência de funções do "centro" para a "periferia" é natural em qualquer administração que tenha ultrapassado certas dimensões, compreendendo não apenas a da administração estatal, mas também a de entidades públicas menores e de grandes entidades empresariais privadas, ativando uma inteligente distribuição de funções e de tarefas, capaz de propiciar um substancial conteúdo e uma operacionalidade real. ${ }^{9}$

O que se verifica é a transformação dos modelos de administração pública, que passam a se situar no desenho organizativo e na gestão de recursos em função da natureza das tarefas, acarretando uma fragmentação harmônica do aparato adminis-

6 "The effect, without considering in any manner the efficiency of the administration, is that the public, except in rare cases, becomes unable to attach responsibility directly to a given subordinate official. It is equally impossible to affix a like responsibility to the Secretary of Agriculture in view of the almost limitless range of his obligations" (James M. Landis, apud Bernard Schwartz, in "American Administrative Law", Sir Isaac Pitman \& Sons Ltda., London, 1950, p. 11).

7 Para uma análise sistemática dos diversos graus de centralização e descentralização, ver Méndez, in "Sistemas Orgánicos", constante da obra coletiva "Perspectivas del Derecho Público en la segunda Mitad del siglo XX”, Madrid, 1969, pp. 951/2 e 956/7.

8 Noberto Bobbio in "Dicionário de Política" BOBBIO, Editora UNB, 1999, trad. Carmen C. Varriale, Vol. 1. pp. 329/330. Também sobre a matéria, ver Alfredo Gallego Anabitarte, in "Transferencia y Descentralización: Delegación y Desconcentración; Mandato y Gestión o Encomienda. Teoría Jurídica y Derecho positivo", constante da obra coletiva "Actualidad y Perspectivas del Derecho Publico a fines del siglo XX - Homenaje al Profesor Garrido Falla", Editorial Complutense, pp. 550/1.

9 In "Dicionário de Política" cit., Vol. 1, pp. 329/330. Também sobre a matéria, ver Alfredo Gallego Anabitarte, in "Transferencia y Descentralización; Delegación y Desconcentración; Mandato y Gestión o Encomienda. Teoría Jurídica y Derecho positivo", constante da obra coletiva "Actualidad y Perspectivas del Derecho Publico a fines del siglo XX - Homenaje al Profesor Garrido Falla". Editorial Complutense, pp. 550/1. 
trativo. a necessidade de novos instrumentos de integração, e o reconhecimento de novos graus de exercício autônomo de discricionariedade, com a emergência de mecanismos de controle mais finalísticos que hierárquicos. ${ }^{10}$

$O$ forte liame existente entre o Direito Administrativo e o Direito Constitucional $^{11}$ fez com que, expressa ou implicitamente, a tão decantada necessidade de descentralização administrativa fosse contemplada em nosso Texto Maior, seja em sua versão originária seja, de forma ainda mais destacada, em suas sucessivas reformas.

A descentralização administrativa na Constituição brasileira decorre do que Diogo de Figueiredo Moreira Neto ${ }^{12}$ qualifica como "os princípios técnico-administrativos de maior relevo na reforma administrativa: ${ }^{13}$ o da autonomia e o da profissionalização".

Segundo o publicista, a Reforma Administrativa implicou "um passo racional na descentralização, com a finalidade de atender as diferentes necessidades de gestão da coisa pública segundo as suas características próprias e não em conformidade com um padrão rígido, formal e predeterminado".

Sem tal flexibilidade, ${ }^{1+}$ não seria possível à Administração, enrijecida em órgãos e funções hierárquica e burocraticamente estruturadas, atuar com eficácia e, muito menos, em um mundo constantemente em mudança, com a eficiência e a economicidade preconizadas, respectivamente, pelos caputs dos arts. 37 e 70 da Constituição Federal, que, ao fixar os fundamentos da República Federativa do Brasil, também

10 Joan Prats i Catalá, in "Derecho y Management en las Administraciones Publicas - Notas sobre la crisis y Renovación de los respectivos paradigmas". pp. 09.12 e 13 (fonte: www.crad.org.ve). Ver também Diogo de Figueiredo Moreira Neto, nas obras "Apontamentos sobre a reforma Administrativa", Ed. Renovar, 1999, p. 04 e ss. e "Sociedade, Estado e Administração Pública", Ed. Topbooks, 1995, pp. 142/4. Por sua vez, R. Zippelius, afirma que "contra um aparelho de Estado totalitário com as dimensões descritas por Orwell existem, pelo menos, prevenções, que por enquanto ainda funcionam. Elas residem na pluralidade estrutural e na divisão de funções" (in Teoria Geral do Estado, trad. Karin Praefke-Aires Coutinho. Coordenação de J. J. Gomes Canotilho, Fundação Calouste Gulbenkian, $3^{a}$ ed., 1997, p. 296).

11 Como afirma Eduardo García De Enterría (in "Curso de Derecho Administrativo". Vol. I, Civitas, Madrid, $9^{\text {a }}$ ed., 1999, pp. 40 e 41), o Direito Administrativo é o Direito Público Interno do Estado por excelência. Sendo assim, a Constituição, com a sua superioridade hierárquico-normativa, penetra com grande intensidade em todos os aspectos da atuação administrativa. A administração pública é a "mais comum e extensa forma de atuação do Estado, o que faz com que se consubstancie em um "Direito Constitucional concretizado" (Werner)".

12 In "Apontamentos sobre a Reforma Administrativa", Ed,. Renovar, 1999 cit., pp. 27 a 29.

13 O autor, naturalmente, está se referindo à Emenda Constitucional $n^{\circ} 19 / 98$.

14 " L'idea decentralista ebbe a trarre forza e vitalità dalle nuovi esigenze dei tempi, dalla nuova posizione assunta dallo Stato come organismo sociale, dall'impellente necessità, sorta dalla complicazione dei rapporti dall'assunzione di nuove funzioni, di regolare com sollecitudine, egualmente e equamente, tutte le manifestazioni della vita collettiva per ogni parte del território. Male infatti, avrebbe potuto provvedere a questa necessità una sola organizzazione amministrativa accentrata. insufficiente ed incapace essa sarebbe apparsa senza la costituzione e il riconoscimento di subcentri $i$ quali concorressero al soddisfacimento dei pubblici bisogni" (Carlo Girola, in "Teoria del Decentramento Amministrrativo", Fratelli Bocca Editore, Torino, 1929. p. 103) 
assegura o "pluralismo do poder na sociedade ( $\operatorname{art} .1^{\circ}, \mathrm{V}$ ), enriquecido na consciência de sua importância tanto quanto à abertura e multiplicidade dos canais para a sua atuação". ${ }^{15}$

Em outra obra, o mesmo autor demonstra que o princípio da eficiência "afasta qualquer burocratização de entidade ou de órgão público além do mínimo indispensável para o cumprimento das suas tarefas de rotina, ou seja, o desempenho das atividades-meio. De resto, todas as tarefas devem ser necessariamente orientadas pela atividade-fim, ou seja, pela finalidade". ${ }^{16}$

"Deste modo, adquiriu-se progressivamente a consciência de que, em relação à questão da descentralização, se trata de um problema de optimização, isto é, da tarefa de criar unidades organizatórias que realizam, caso a caso um compromisso óptimo: entre as necessidades antagónicas de proximidade do assunto e do cidadão, auto-administração e auto-responsabilidade, por um lado, e regulação uniforme, coordenação e responsabilidade global, por outro". ${ }^{17}$

Não há, portanto, antagonismo entre a autonomia de entidades e órgãos descentralizados com a unidade da Administração, muito pelo contrário: a Administração Pública contemporânea, para cumprir as suas funções e atender aos valores e princípios constitucionais a ela impostos, deve atuar, ao mesmo tempo, coordenada e descentralizadamente. ${ }^{18}$

\section{II - A descentralização autárquica}

Como evolução/contraposição ao modelo centralista, napoleônico, de Administração Pública, ${ }^{19}$ a autonomia no desempenho de parcelas das atividades estatais se

15 Diogo de Figueiredo Moreira Neto, in "Curso de Direito Administrativo", Ed. Forense, $9^{2}$ ed., 1990, p. 99. Para muitos autores o princípio da descentralização também constitui emanação do princípio da subsidiariedade, pelo qual o Estado central só deve assumir as atribuições, as tarefas ou as incumbências que outras entidades existentes no seu âmbito e mais próximas das pessoas, dos seus problemas concretos, não possam assumir e exercer melhor e mais eficazmente (cf. Jorge Miranda, in Manual de Direito Constitucional, Tomo III, Coimbra Editora, $4^{a}$ ed., 1998). Como também ressalta Reinhold Zippelius, "a regulação de conflitos de interesses socialmente relevantes concretiza-se de maneira particularmente nítida em sociedades pluralistas, pela acção conjunta de todo um complexo de subsistemas" (in "Teoria Geral do Estado", trad. Karin Praefke-Aires Coutinho, Coordenação de J. J. Gomes Canotilho, Fundação Calouste Gulbenkian, $3^{a}$ ed., 1997, p. 27). Ainda ligando a idéia de descentralização administrativa à liberdade individual e à democracia pluralista, A. Salandra, in "Corso di Diritto Amministrativo", C. Manes, Roma, Atheneum, 1915, II, p. 39, passim.

16 In Mutações do Direito Administrativo, Ed. Renovar, 2000, p. 24.

17 Reinhold Zippelius, in ob. cit., p. 129.

18 "A pluralidade dos centros de autonomia política, nos quais se expande o moderno ordenamento democrático, não significa desarticulação e atomização das suas estruturas" (Enrico Spagna Musso, in "L'Iniziativa nella Formazione della Legge Italiana", Napoli, 1958, p. 95).

19 Eduardo García de Enterría descreveu o modelo administrativo napoleônico da seguinte maneira: "as funçōes ativas se reservam apenas aos órgãos com agentes individuais ou monocráticos, os 
iniciou através da criação pelo Estado de pessoas jurídicas a ele paralelas, especialmente autarquias - pessoas jurídicas com personalidade jurídica de Direito Público - , denominadas entre nós de entidades da Administração Indireta.

É, contudo, necessário observar que a mera criação de autarquia ou de qualquer outra espécie de ente da Administração Indireta, sem que possua um grau de razoável autonomia para desenvolver suas atribuições, não torna o seu desempenho mais ágil e eficiente, não as caracterizando como entidades descentralizadas em sentido material, ou seja, efetivo, verdadeiro, constituindo, outrossim, entidades apenas formalmente descentralizadas.

Neste sentido, Alfredo Gallego Anabitarte ${ }^{20}$ denotou que "também se pode produzir a verdadeira descentralização em um sujeito ou centro de competências que não seja personalizado. (...) Não é essencial à descentralização que o sujeito descentralizado seja titular da competência que se lhe transfere (...). A usual definição de descentralização como "transferência da titularidade de competências entre pessoas jurídicas" não é mais que uma das hipóteses - a mais usual — de descentralização. Por outro lado, pode produzir-se esta transferência entre pessoas jurídicas como o caso das entidades da Administração Indireta, mas pode, todavia, não haver verdadeira descentralização em virtude da completa, e lógica tutela, a que se submete a atuação destas pessoas jurídicas."

Em todos estes casos haverá descentralização se forem outorgadas prerrogativas e garantias suficientes ao desempenho autônomo de funções destacadas do poder central. ${ }^{21}$ A nota fundamental é a não subordinação hierárquica.

Em alguns casos, pela amplitude da autonomia do órgão ou entidade, a descentralização revela-se bastante clara. Em outros, entramos em zona grísea, na qual a

quais se relacionam entre si mediante a técnica do escalonamento hierárquico, enquanto que os órgãos colegiais ficam reduzidos a funções consultivas ou deliberativas situadas lateralmente à linha hierárquica, assistindo-a e complementando-a, mas sem diminuir a sua substantividade e prevalência" (in "Revolución Francesa y Administración Contemporánea", Civitas, 4" ed., 1998, p. 125). 20 In "Transferencia y Descentralización; Delegación y Desconcentración: Mandato y Gestión o Encomienda. Teoría Jurídica y Derecho positivo", constante da obra coletiva "Actualidad y Perspectivas del Derecho Publico a fines del siglo XX - Homenaje al Profesor Garrido Falla", Editorial Complutense", pp. 552/3 (grifamos). O conceito de descentralização efetiva também encontra esteio na doutrina de Reinhold Zippelius: “Trata-se de desconcentração quando os membros de uma organização estão totalmente vinculados a instruções de instância central, e de descentralização quando estes membros gozam, no exercício das suas funções, de uma grande autonomia, p. ex., se unicamente se acham sujeitos a uma tutela de legalidade central ou, quando muito, a uma limitada tutela de mérito" (in ob. cit., p. 127, grifamos).

21 "La décentralisation implique que, pour assurer la marche de certains groupements de services, existent d'autres corps d'administration ayant une certaine liberté d'action. Le pouvoir central n'est pas eliminé, mais son rôle change. Il ne dirige plus. Il se borne à contrôler les autorités placées à la tête de ce corps d'administration propre" (Maurice Hauriou, in "Précis de Droit Administratif", Dalloz, 1926, 92). Também vinculando o conceito de descentralização administrativa ao de autonomia, que seria um requisito daquela, A. Salandra, in "Corso di Diritto Amministrativo", C. Manes, Roma, Atheneum, 1915, II, p. 39, passim. 
efetiva descentralização, por já não se mostrar tão evidente, exigirá mais do intérprete para ser constatada.

Com efeito, as leis costumam denominar as entidades da Administração Indireta de autônomas, e, realmente, como pessoas jurídicas que são, não podem deixar de ser dotadas de alguma autonomia. ${ }^{22}$ No que diz respeito especificamente às autarquias. leis há que, para tentar corroborar a sua autonomia, conferem-lhes a denominação de "autarquias de regime especial".

A disciplina legal dada à autonomia destas entidades é, porém. muitas vezes, bastante restrita. Esta autonomia mínima, inerente a qualquer pessoa jurídica, não nos parece. já o vimos. capaz de caracterizar a descentralização. Em alguns casos, há até mesmo a previsão genérica do chamado recurso hierárquico impróprio, pelo qual um ato da entidade da Administração Indireta pode ser anulado por agente do Estado, pessoa jurídica dela distinta.

Dessarte, há alguns anos a tendência originária de descentralização sofreu um revés, não pela extinção de pessoas jurídicas da Administração Indireta, mas pela redução de sua autonomia, para o que muito contribuíram os abusos praticados em virtude da maior flexibilidade das regras a elas aplicáveis, abusos estes que as desvirtuaram dos objetivos e das necessidades que levaram à sua criação.

Foi assim que o Direito Positivo Brasileiro, buscando resgatar a autonomia e a descentralização material das autarquias e demais entidades da Administração Indireta, resguardando-as, porém, dos excessos verificados no passado, criou os institutos das agências executivas e dos contratos de gestão.

\section{III - As agências executivas}

Não há como delimitarmos a profundidade e a extensão do conceito das agências executivas sem fazê-lo conjuntamente com a análise dos contratos de gestão, instituto a elas co-natural.

Figura nova no Direito Brasileiro, os contratos de gestão ${ }^{23}$ podem ser celebrados com entidades privadas da sociedade civil que, nos termos da Lei n. ${ }^{\circ} 9.637 / 198$,

22 Essa autonomia mínima revela-se, por exemplo, na impossibilidade do Poder Executivo, de forma imediata, incorporar na entidade da Administração Indireta normas por ele expedidas. A este respeito, o Procurador do Estado do Rio de Janeiro, Luiz Carlos Guimarães Castro, no Parecer ${ }^{\circ}$ 08/90 LCGC, tratando do Decreto Estadual n 19.923/94, que dispõe que a cessão dos bens das sociedades de economia mista está sujeita à prévia autorização governamental, afirmou: "É, pois, neste sentido do comportamento do Estado-acionista, do procedimento de direção dos seus órgãos descentralizados, que me parece se possa admitir a expedição, pelo Estado, de atos de império (leis e decretos), não atingindo, porém tais atos o comportamento da própria pessoa jurídica (...) Para reger a pessoa jurídica descentralizada, dever-se-ia prever a inclusão do procedimento nos respectivos estatutos: em caso contrário, qualquer contrato envolvendo terceiros e porventura firmado em desconformidade com o comando contido no decreto, não poderia ser, por este só motivo, inquinado de nulidade (...)".

23 Para uma análise histórica dos contratos de gestão, que seriam originários da França, ver Maria Sylvia Zanella Di Pietro (in "Parcerias na Administração Pública", Ed. ATLAS, 1997, pp. 132 a 
venham a ser consideradas organizações sociais, ou com órgãos ou entidades da Administração Pública qualificados como agências executivas, na forma do art. 37. $\S 8^{\circ}$ da Constituição Federal (acrescido pela Emenda Constitucional no 19/98) e, no âmbito da União, do art. 51 da Lei $n^{\circ} 9.649 / 98$ e do Decreto $n^{\circ} 2.487 / 98$, este colacionado às fls. 17/21 dos autos.

Para os objetivos da consulta, as organizações sociais não têm relevância, vez que não constituem instrumentos de autonomização de órgãos ou entidades do Estado, mas sim um dos possíveis mecanismos de atração de entidades da sociedade civil - o chamado terceiro setor -, para a esfera pública.

Outrossim, a instituição das agências executivas teve como principal objetivo justamente possibilitar a gestão autônoma de entidades ou órgãos públicos. Estes não perdem a sua natureza originária (de órgãos, de autarquias etc.), passando apenas a ser qualificados como "agências executivas" e, depois de celebrado o contrato de gestão com a Administração central, a possuir maior autonomia gerencial, orçamentária e financeira.

As agências executivas, inicialmente existentes apenas no âmbito da União, vieram a ser constitucionalizadas para todos os Entes da Federação pela Emenda Constitucional $n^{\circ}$ 19/98, que, ao dar nova redação ao art. 37 da Constituição Federal, dispôs:

§ 8 A autonomia gerencial, orçamentária e financeira dos órgãos e entidades da administração direta e indireta poderá ser ampliada mediante contrato, a ser firmado entre seus administradores e o poder público, que tenha por objeto a fixação de metas de desempenho para o órgão ou entidade, cabendo à lei dispor sobre:

I - o prazo de duração do contrato;

II — os controles e critérios de avaliação de desempenho, direitos, obrigações e responsabilidade dos dirigentes;

III - a remuneração do pessoal.

Desta forma, a Reforma Administrativa, acrescentando o $\S 8^{\circ}$ do art. 37 da Constituição Federal, preceituou que os órgãos ou entidades da Administração Indireta podem, após serem qualificados como agências executivas, ter a sua autonomia ampliada mediante a celebração de contratos de gestão com o Poder Executivo central, cabendo à lei dispor sobre o prazo do contrato, os controles e critérios de avaliação de desempenho, os direitos e responsabilidades dos dirigentes e a remuneração do seu pessoal, aspecto de grande importância por admitir interpretações

140) e René Chapus (in "Droit Administratif Général", Tomo 1. Ed. Montchrestien, 13ª ed., 1999, pp. 414/5). 
que possibilitem a não incidência sobre as agências executivas de algumas das normas constitucionais sobre a remuneração dos servidores públicos.

Independentemente de suas potencialidades jurídicas, a criação das agências executivas e dos contratos de gestão teve, em grande parte, o papel de manifestar a vontade política de se realizar uma reestruturação da Administração Pública. ${ }^{24}$

Preliminarmente, devemos observar que os contratos de gestão celebrados com as agências executivas não são verdadeiros contratos, já que estes pressupõem a duplicidade de partes e a reciprocidade de interesses, ou seja, a existência de duas pessoas jurídicas com interesses próprios. ${ }^{25}$

$\mathrm{Na}$ concepção dos próprios idealizadores da Reforma Administrativa, o contrato de gestão "estaria identificado com o princípio da "individualização da autonomia". (...) Consistiria em toda relação negociada entre o Poder Público e suas instâncias operativas. Trata-se, portanto, de uma relação de natureza interna, estabelecida de modo particular, buscando maior eficiência mediante formas alternativas de controle que privilegiam a autonomia gerencial e os resultados, e não os meios de ação administrativa". ${ }^{26}$

Sendo assim, os contratos de gestão celebrados com entidades ou órgãos públicos qualificados como agências executivas devem ser vistos como acordos organizativos de natureza normativa, de caráter regulamentar, que têm de "contrato" apenas o nome.

Na Itália, país no qual a celebração de instrumentos desta natureza não é um fenômeno novo, são considerados como uma das maneiras da Administração Pública organizar-se internamente.

24 Celso Antônio Bandeira de Melo, talvez com um pouco de exagero, enfoca a matéria da seguinte maneira: "Se isto impressiona os administradores públicos, economistas ou, mesmo, outros agentes, levando-os a se esmerarem no cumprimento de certos objetivos e metas, é importantíssimo que se realizem tais encenações, dada a utilidade concreta que podem produzir, na medida em que psicologicamente influem de modo positivo no espírito de seus agentes. Tratar-se-á, em tal caso, de dramatização, pois, ao que parece, figurações de gênero, conquanto sejam juridicamente irrelevantes, sensibilizam muito administradores e economistas" (in "Curso de Direito Administrativo", Malheiros, $11^{\text {a }}$ ed., 1999, p. 150). No mesmo sentido, tratando de instituto análogo no Direito espanhol, Ramón Parada afirmou que "la calificación como contrato presenta así un valor mítico, pero juridicamente se revela poco operativa" (in "Derecho Administrativo", Tomo I, Marcial Pons, 1999, p. 272).

25 Neste sentido, a própria equipe que elaborou a proposta de reforma constitucional que deu origem ao art. $37, \S 8^{\circ}$ da Constituição Federal (in "O Contrato de Gestão no Serviço Público", Secretaria da Administração Federal, ENAP, Brasília, 1993, pp. 107/9), Celso Antônio Bandeira de Melo (in ob. cit., pp. 144/5 e 152/4), Jessé Torres Pereira Junior (in "Da Reforma Administrativa Constitucional", Ed. Renovar, Rio de Janeiro, pp. 173/4) e Maria Sylvia Zanella Di Pietro (in "Direito Administrativo", Ed. ATLAS, $11^{\text {a }}$ ed., 1999, p. 283). Esta última destaca que, mesmo quando tenham como partes pessoas jurídicas distintas, ou seja, quando o contrato de gestão for celebrado entre entidade da Administração Indireta e o Ente Federativo central, não se tratará de contrato por não haver antagonismos de interesses: "É inconcebível que os interesses visados pela Administração Direta e Indireta sejam diversos".

26 In O Contrato de Gestão no Serviço Público, Secretaria da Administração Federal, ENAP, Brasília, 1993, p. 105. 
Com efeito, observa a doutrina italiana que "o uso destes instrumentos convencionais por parte da Administração coloca problemas de natureza dogmática (...). As convenções organizativas se apresentam exteriormente como acordos, tendo como partes duas figuras subjetivas públicas, que podem ser dois órgãos, um órgão e um ente, ou mais de um ente (...). Esta análise elementar mostra que "convenção administrativa" não é uma expressão científica, mas da prática: quer-se indicar os atos bi- ou plurilaterais, com os quais o Poder Público cuida, por acordo, do interesse público". Estamos diante de "acordos com conteúdo normativo." 27

Contudo, apesar das impropriedades técnicas, conscientes ou não, verificadas na criação das agências executivas e dos contratos de gestão, os institutos podem revelar potencialidades que só o tempo mostrará. Na pior das hipóteses, deles exsurge a intenção do Constituinte Derivado em aumentar a descentralização e a consensualidade da Administração Pública.

Não são, todavia, as agências executivas e os contratos de gestão, os únicos meios pelos quais entidades ou órgãos da Administração Pública podem adquirir maior autonomia. Como a autonomia orgânica é matéria de organização interna de cada Ente da Federação, nada impede que o próprio Ente, independentemente da "lei regulamentadora" do art. $37, \S 8^{\circ}$ da Constituição Federal, no exercício dos poderes ordinários de organização da Administração Pública, amplie a autonomia de alguns dos seus órgãos ou entidades, desde que não excepcione normas constitucionais ou atinja aspectos protegidos pelo princípio da legalidade (remuneração de servidores públicos, aplicação de penalidades não previstas na legislação etc.).

Em outras palavras, os Entes da Federação prescindem da lei regulamentadora do $\S 8^{\circ}$ do art. 37 da Constituição Federal para, dentro dos lindes da Constituição, mas sem alcançar as potencialidades propiciadas pelas agências executivas, exercer a sua competência de estabelecer normas de organização interna, dando maior ou menor autonomia às suas partes constitutivas.

O que deve ser frisado é que, se a assertiva é verdadeira em relação aos aspectos meramente organizatórios da Administração Pública, não é correta no que diz respeito à incidência do $\S 8^{\circ}$ do art. 37 da Constituição Federal, que pode propiciar exceções à aplicação de normas da própria Constituição, principalmente em matéria de pessoal. Não poderíamos, com efeito, conceber que a Reforma Administrativa tenha operado uma alteração na Constituição para alcançar o que qualquer lei ou decreto regulamentar organizativo poderia ter feito.

De fato, a concessão de autonomia mediante a qualificação como agências executivas e a subsequiente celebração de contrato de gestão possui, dada a sua sede constitucional, possibilidades que a mera concessão de autonomia mediante decreto ou mesmo através de lei, não seria capaz de oferecer.

27 Massimo Severo Giannini, in "Diritto Amministrativo", Volume I, Giuffrè Editore, Milāo, 3" ed., 1993,, pp. 366 a 371 . Também se colocando a favor da natureza normativa destes acordos administrativos, pronunciou-se Rosário Ferrara: " $L$ 'accordo sembra infatti possedere valenza "normativa", in quanto costituisce il punto di aprobo di um regolamento "negoziale" di interessi (...)" (in "Gli Accordi di Programma", CEDAM, Padova, 1993, p. 121). 
O mesmo se deve dizer quanto à aplicação do parágrafo único do art. 24 da Lei Nacional de Licitações e Contratos Administrativos, que amplia as excepcionais hipóteses de dispensa de licitação por reduzido valor do objeto contratual.

Naturalmente que sempre é o Poder Executivo que qualifica concretamente esta ou aquela entidade como agência executiva, mas, para que alcance todas as suas potencialidades, inclusive para que seja aplicado o parágrafo único do art. 24 da Lei $n^{\circ} 8.666 / 93$. a qualificação só surtirá efeitos se realizada nos termos da lei regulamentadora prevista no $\S 8^{\circ}$ do art. 37 da Constituição Federal. ${ }^{28}$

O citado dispositivo legal é, nesta senda, bastante claro quando admite o aumento do valor para as hipóteses de dispensa de licitação previstos em seus incisos I e II apenas para a "autarquia e fundação qualificadas, na forma da lei, como Agências Executivas".

Como não há lei regulamentando as agências executivas no âmbito do Estado do Rio de Janeiro, não há como a ASEP-RJ ser considerada como tal.

Poder-se-ia redargüir imaginando-se que a própria Lei que instituiu a ASEP-RJ, a Lei $n^{\circ} 2.666 / 97$, ao denominá-la de "agência reguladora" e ao atribuir-lhe uma série de prerrogativas e poderes autônomos, atenderia à reserva de lei enunciada pelo $\S 8^{\circ}$ do art. 37 da Constituição Federal e pelo parágrafo único do art. 24 da Lei $n^{\circ}$ 8.666/93. Para espancar quaisquer dúvidas a respeito deste entendimento é necessário adentrarmos no conceito de agência reguladora, ao qual será destinado o Tópico a seguir.

\section{IV - As agências reguladoras}

O movimento visto acima de retorno à descentralização material das entidades da Administração Indireta, em razão da grande onda de privatização dos serviços públicos, ${ }^{29}$ foi, por esta razão, fortalecido pela criação de novas entidades e órgãos independentes, ${ }^{30}$ encarregados da sua supervisão e normatização.

28 Vemos, assim, que $\circ \S 8^{\circ}$ do art. 37 da Constituição Federal se subsume, dentro da conhecida classificação de José Afonso da Silva ("Aplicabilidade das Normas Constitucionais", Ed. Malheiros, São Paulo) das normas constitucionais, como uma norma de eficácia limitada, no sentido de necessitar de norma infra-constitucional regulamentadora para adquirir a sua plena eficácia.

29 Como sói acontecer no Direito Público, a discrepância de nomenclatura é grande. No particular, adotamos, com Celso Antonio Bandeira de Mello (in "Privatização e Serviços Públicos", RTDP, 22, pp. 172 a 180), o termo "privatização" para os serviços públicos cuja execução foi delegada à iniciativa privada e "desestatização" para as atividades econômicas que deixaram de ser exploradas por entidades estatais.

30 Naturalmente que o termo "independência" aqui utilizado não é equivalente a "soberania", mas sim a uma efetiva descentralização autônoma, conceito que, como retro delimitado, não exclui a coordenação pela Administração central. 
A este respeito, GIAMPAOLO ROSSI, ${ }^{31}$ após expor o malogro das tentativas de desregulação da economia. ${ }^{32}$ afirma que grande parte da atividade reguladora vem sendo confiada a autoridades administrativas independentes e especializadas, que "surgem como cogumelos depois do sereno do outono" (sorgono come funghi dopo la pioggia in autunno).

Com efeito, verificada a necessidade de retração da intervenção estatal em vastos setores da vida econômica, teve-se, por outro lado, a consciência de que o Estado não poderia deixar apenas ao bom senso empresarial a gestão de atividades de indubitável interesse público, devendo estas, portanto, ficar sob o seu poder regulatório.

Apesar da sua origem relativamente antiga, que tem como principal marco a Interstate Commerce Commission, criada nos Estados Unidos da América do Norte em 1887 para regulamentar os serviços interestaduais de transporte ferroviário, ${ }^{33}$ as agências reguladoras constituem, cada vez mais, um importante mecanismo de diálogo entre o Direito, que não pode abrir mão do seu caráter normativo, e a economia, que não cessa de aumentar a capacidade de impor a sua própria lógica. ${ }^{34}$

Como consequiência necessária desta conjuntura, foram conferidos amplos poderes, notadamente de natureza normativa, às agências reguladoras, ${ }^{35}$ que, de outra forma, não poderiam desempenhar satisfatoriamente (agilidade, informalidade, constante adaptação à realidade cambiante etc.) suas atribuições, exigindo ainda um corpo de titulares revestidos das prerrogativas necessárias à manutenção da sua impermeabilidade face aos interesses econômicos e políticos transitórios.

31 In "Pubblico e Privato nell'Economia di Fini Secolo", constante da obra coletiva "Le Trasformazioni del Diritto Amministrativo", Giuffrè Editore, Milāo, 1995, p. 238.

32 Corroborando a assertiva. afirmou Reinhold Zippelius: "Na sociedade industrial, a auto-regulação dos processos económicos ou até de todos os processos sociais, esperada pelo liberalismo, não funciona na medida exigível. Na sociedade abandonada a si própria, formam-se grandes grupos de poder económico, provocando um grave risco para uma harmonização equilibrada e justa dos interesses" (in "Teoria Geral do Estado", Fundação Calouste Gulbenkian, $3^{a}$ ed., 1997, trad. Karin Praefke-Aires Coutinho, Coordenação de J. J. Gomes Canotilho, p. 462).

33 Bernard Schwartz, ob. cit., pp. 6 e 7.

34 "O direito moderno mantém elevada interdependência com os demais sistemas (p. e., econômico, político, científico etc.), e é sensivel às demandas que lhe são formuladas por este ambiente (abertura cognitiva); entretanto. só consegue processá-las nos limites inerentes às estruturas, seleções e operaçōes que diferenciam o direito dos demais sistemas (fechamento operativo). Dessa perspectiva, o sistema jurídico é um só, pouco importando se as cadeias normativas são múltiplas, não-hierarquizadas, informais ou produzidas em diferentes contextos. Essa unicidade decorre da função do direito e não da arquitetura do sistema normativo. A globalização demanda novas diferenciações no interior do sistema jurídico, mas não é capaz de corromper sua funçäo" (Celso Fernandes Campilongo, "Teoria do Direito e Globalização Econômica", in Direito Global, Max Limonad, 1999 , p. 80 - grifamos).

35 Hughes, in "Some Aspects of Development of American Law", 1916, 39, New York State Bar Association Reports, 266, 269. 
Juan Carlos Cassagne ${ }^{36}$ observa que os poderes conferidos a estes órgãos e entidades são de "variada natureza e extensão". O panorama é amplíssimo, abrangendo os clássicos poderes administrativos relacionados com a fiscalização das atividades desenvolvidas pelos particulares, cumprimento das regras estabelecidas nos contratos de concessão, nas licenças ou nas autorizações, incluindo o estabelecimento de eventuais tarifas, poderes disciplinares, sancionatórios e preventivos de condutas prejudiciais aos interesses coletivos tutelados.

Sendo assim, as agências reguladoras são entidades "atípicas em relação ao tradicional aparato administrativo, com acentuada característica de independência decisória e alta competência técnica, normalmente colegiadas, ${ }^{37}$ que ditam regras de comportamento aos operadores, os fiscalizam, aplicam-lhes sanções e formulam propostas ao Parlamento e ao Governo." 38

Relacionando-se com o próprio Princípio da Separação dos Poderes, ${ }^{39}$ as exigências de autonomia das agências reguladoras vão além da simples descentralização material.

A autonomia das agências reguladoras existe, em maior ou em menor escala, frente a todos os Poderes do Estado, revelando-se mais sensível face ao Poder Executivo, tendo em vista o maior número de pontos de contato que com ele possui, e a tradicional, mas ultrapassada, idéia de subordinação hierárquica ao Chefe do Governo de todos os agentes e entidades do aparato administrativo.

Neste sentido, podemos afirmar, obter dicta, que, além da atribuição de receitas próprias, ${ }^{40}$ é fundamental para a garantia da independência das agências reguladoras

36 In "Los Nuevos Entes Regulatorios", integrante da obra coletiva "El Derecho Público Actual", Ediciones Depalma, Buenos Aires, 1994, pp. 45/6.

37 Quanto à instituição de órgãos de natureza colegiada como forma de controle, ver R. Zippelius, in ob. cit., p. 410: "Mesmo a estruturação interna de um órgão estatal segundo o princípio colegial tem uma função de controlo."

38 Elisabetta Bani (in "Stato Regolatore e Autorità Indipendenti", constante da obra coletiva "Le Trasformazioni del Diritto Amministrativo", Giuffrè Editore, Milão, 1995, pp. 22/3), define as autoridades administrativas independentes como "il fenomeno, emerso nell'esperienze più recente, delle c. d. autorità amministrative indipendenti, dotate o meno di personalità giuridica, costitute dalla legge per governare determinati settori di amministrazione in senso sostanziale, secondo moduli organizzativi e funzionali del tutto svincolati da qualsiasi relazione com l'organizzazzione ministeriale". Nas páginas seguintes, a autora trata especificamente de cada órgão independente existente no direito italiano, bastante similares às nossas agências reguladoras.

39 Gérard Timsit, em colóquio realizado na Universidade de Paris I - Panthéon-Sorbonne, afirmou, em relação aos possíveis conflitos entre os poderes das agências reguladoras e a concepção clássica de separação de poderes, que o apego a antigos e, já de algum tempo, ultrapassados dogmas do Estado, inviabiliza qualquer elaboração teórica consistente acerca das entidades reguladoras independentes. Assevera que "o problema, em um Estado que desejamos que se mantenha como um Estado de Direito, não é o de absorver ou excluir, de alinhar ou de refutar estas novas instâncias ou instituiçōes. O problema é antes de inventar novas formas e técnicas de controle sobre os novos tipos de autoridades" (in "Les Autorités Administratives Indépendantes", coord. Claude-Albert Colliard e Gerard Timsit, PUF, 1988, pp. 317/8) 
a nomeação dos seus dirigentes por termo certo e mediante procedimento especial, normalmente com a prévia aprovação das indicações pelo Poder Legislativo, e a vedação de exoneração ad nutum.

Ambas as restrições, ao poder de livre nomeação e exoneração pelo Chefe do Poder Executivo, foram consideradas constitucionais pelo Supremo Tribunal Federal no julgamento da Medida Cautelar pedida na $\mathrm{ADIN}^{\circ}{ }^{\circ}$ 1949-0. A primeira em virtude do art. 52, III, "f", da Constituição Federal, admitir a prévia aprovação do Senado Federal da escolha de "titulares de outros cargos que a lei determinar". Quanto à constitucionalidade da vedação da exoneração ad nutum dos dirigentes das agências reguladoras, o Supremo entendeu que não viola as competências do Chefe do Poder Executivo, admitindo a exoneração apenas por justa causa e mediante o prévio procedimento administrativo, assegurado o contraditório e a ampla defesa, ou se advier a mudança da lei criadora da agência independente. ${ }^{41}$

Catherine Teitgen-Colly, ${ }^{42}$ ao analisar as autoridades administrativas independentes francesas, equivalentes às nossas agências reguladoras, observa que têm a função de regulação social em determinados setores, função a qual o respectivo grupo social adere. São estas funções que justificam a estrutura e os poderes, inclusive de fixar regras jurídicas, destas instituições, que "não são subordinadas ao Poder Executivo, nem são prolongamentos do Poder Legislativo ou Judiciário, e que são dotadas de poderes que lhes permite exercer de forma independente uma missão de regulação setorial."

As apontadas características das agências reguladoras, ${ }^{43}$ quais sejam, (a) a especialização técnica e setorial, (b) os amplos poderes decisórios, notadamente de natureza normativa, e (c) a elevada autonomia frente ao Poder Executivo central, não fazem com que sejam instituições homogêneas entre si, havendo, contudo, em todas elas, os traços comuns de autonomia face ao Poder Executivo central. ${ }^{44}$

40 Quanto à natureza destas receitas remetemos o leitor ao artigo "Agências Reguladoras" (RDA, 216), de Marcos Juruena Villela Souto, pp. 125 e ss. O autor considera que as quantias cobradas pela fiscalização dos delegatários de serviços públicos, fiscalização esta, a seu ver, de natureza contratual, constitui preço público, e não taxa.

41 Dissonantemente, o Relator, Ministro Sepúlveda Pertence, entendeu aplicável à espécie a Súmula $n^{\circ} 25$, que dispõe: " A nomeação a termo não impede a livre demissão, pelo Presidente da República, de ocupante de cargo de dirigente de autarquia" (fonte: www.stf.gov.br). Note-se, contudo, que, apesar de nāo ser muito notado pela doutrina, a Súmula $\mathrm{n}^{\circ} 25$ nunca foi tomada em termos absolutos, tendo sido, por exemplo, excepcionada em relação aos reitores das universidades públicas, geralmente de natureza autárquica, conforme o que dispõe a Súmula 47: "Reitor de Universidade não é livremente demissível pelo Presidente da República durante o prazo de sua investidura."

42 In "Les autorités Administratives Indépendantes: histoire d'une institution", constante da obra coletiva "Les autorités Administratives Indépendantes" cit., pp. 23/4.

43 Antonio la Spina e Giandomenico Majone, Lo Stato Regolatore, Ed. Il Molino, Bologna, 2000, p. 62.

44 Há, de fato, uma grande heterogeneidade das agências reguladoras: algumas são dotadas de considerável extensão de poderes autônomos, outras nem tanto, havendo ainda as que sequer podem ser consideradas como "independentes" ou autônomas, se descaracterizando, desta forma, como verdadeiras agências. 
A esta altura podemos constatar as grandes diferenças existentes entre as agências reguladoras e as agências executivas, que possuem em comum apenas o primeiro nome e a idéia de autonomia, concretizada esta, todavia, de forma inteiramente diversa em cada um dos institutos.

A caracterização de uma autarquia como agência reguladora diz respeito à natureza das suas funções, destas decorrendo a necessidade de possuir poderes autônomos, capazes de fazer com que desempenhem "um papel contínuo de observação da atividade regulada, avaliação dos interesses em jogo e de ajustamento e reajustamento das regras às circunstâncias". ${ }^{45}$

É em virtude da natureza das suas funções que as respectivas leis instituidoras as revestem. diretamente. de uma série de prerrogativas de autonomia, principalmente em suas atividades-fim, e, apenas por via de consequiencia, em suas atividades-meio.

Situação inteiramente diversa é a das agências executivas, mera qualificação conferida a órgãos despersonalizados ou a entidades da Administração Indireta, que, com isto, não perdem e não têm alterada a sua natureza e o seu círculo competencial originário.

$\mathrm{O}$ instituto das agências executivas representa apenas a possibilidade de uma maior autonomia gerencial interna - nas suas atividades-meio -, livrando as entidades assim qualificadas de uma série de entraves burocráticos e hierárquicos aplicáveis ao restante da Administração Pública.

Ademais, a autonomia das agências reguladoras advém, como visto, diretamente da lei, ao passo que a autonomia gerencial das agências executivas promana da qualificação concretamente feita pelo Poder Executivo central, dentro dos quadros estabelecidos pela lei regulamentadora do $\S 8^{\circ}$ do art. 37 da Constituição Federal.

Naturalmente que nada impede, ao revés, aconselha. que as agências reguladoras, além da autonomia finalística, oriunda diretamente das suas leis instituidoras, venham a gozar de uma maior autonomia gerencial através da qualificação como agências executivas.

Isso revela que a caracterização de uma autarquia como agência reguladora decorre das suas amplas competências legais, de caráter normativo, em determinado setor da atividade humana e, principalmente, das prerrogativas dos seus dirigentes frente ao Poder Executivo central. Desta configuração jurídica nada se pode inferir que as qualifique, de per se, como agências executivas.

A qualificação desta ou daquela autarquia, ou qualquer outro órgão ou entidade da Administração Pública, como agência executiva é ato do Poder Executivo central praticado dentro dos balizamentos da lei regulamentadora referida no $\S 8^{\circ}$ do art. 37 da Constituição Federal, a ser expedida por cada Ente federativo.

Naturalmente que. repise-se, a lei instituidora de determinado órgão ou entidade, ou mesmo ato regulamentar do Poder Executivo, podem assegurar determinada autonomia gerencial, administrativa e financeira, o que, no caso da ASEP-RJ, é feito pelo art. $1^{\circ}$ da Lei $\mathrm{n}^{\circ} 2.666 / 97$. 
Mas a simples existência de certa esfera de autonomia, não iguala estes órgãos ou entidades às agências executivas, dotadas, após a celebração dos respectivos contratos de gestão, de uma autonomia especial, de sede constitucional, apta mesmo a, eventualmente, excepcionar determinadas normas constitucionais, e, a, nos termos do parágrafo único do art. 24 da Lei $n^{\circ} 8.666 / 93$, aumentar os valores-limite das dispensas de licitação previstos nos incisos I e II do mesmo artigo.

Espancando qualquer dúvida hermenêutica, o próprio parágrafo único do art. 24 da Lei $\mathrm{n}^{\circ}$ 8.666/93 trata apenas da "autarquia e fundação qualificadas, na forma da lei, como Agências Executivas", quando poderia, se outra tivesse sido a intenção do Legislador ou do Constituinte Derivado, aludir simplesmente à "autarquia ou fundação dotada de autonomia".

\section{Conclusão}

Após as digressões efetuadas, necessárias em virtude da novidade que os institutos envolvidos representam no ordenamento jurídico brasileiro, podemos concluir que:

1. As agências reguladoras e as agências executivas, surgidas no Brasil no mesmo momento de mudança das estruturas administrativas tradicionais, hierarquizadas, apesar da semelhança de nomenclatura, constituem institutos diversos;

2. As agências reguladoras são entidades caracterizadas pelos largos poderes normativos que possuem em determinado setor, e pelas prerrogativas dos seus dirigentes;

3. As agências executivas constituem mera qualificação dada a órgãos ou entidades da Administração Pública de qualquer espécie, que mantém a sua natureza originária, e que, depois de celebrado o contrato de gestão com a Administração central, adquirem ou aumentam a sua autonomia gerencial;

4. A natureza das agências reguladoras decorre diretamente das suas respectivas leis instituidoras, dos poderes normativos e das prerrogativas funcionais nelas contempladas;

5. A qualificação como agência executiva é feita por ato do Poder Executivo central, dentro dos lindes da lei regulamentadora prevista no $\S 8^{\circ}$ do artigo 37 da Constituição Federal, norma constitucional de eficácia limitada;

6. Destarte, a autonomia que um órgão ou entidade goze como agência executiva deriva do ato formal de sua qualificação como tal, não se confundindo com a mera garantia de certo âmbito de autonomia feita por lei ou por regulamento, fora dos parâmetros traçados pela lei regulamentadora do $\S 8^{\circ}$ do artigo 37 da Constituição Federal;

7. Tanto é assim, que o parágrafo único do art. 24 da Lei $n^{\circ} 8.666 / 93$, ao aumentar os valores das dispensas de licitação previstos nos incisos I e II do mesmo artigo, se refere apenas à " autarquia e fundação qualificadas, na forma da lei, como Agências Executivas";

8. O Estado do Rio de Janeiro ainda não editou a lei regulamentadora do $\S 8^{\circ}$ do art. 37 da Constituição Federal, não havendo, portanto, no âmbito da sua Admi- 
nistração autárquica e fundacional, qualquer entidade que possa atender aos requisitos de incidência do Parágrafo Único do art. 24 da Lei ${ }^{\circ}$ 8.666/93; e

9. A Agência Reguladora de Serviços Públicos Concedidos do Estado do Rio de Janeiro - ASEP-RJ é uma agência reguladora, mas não é. nem poderia ser, pelo menos até o Estado regulamentar o $\S 8^{\circ}$ do art. 37 da Constituição Federal, uma agência executiva, sendo-lhe, desta forma, inaplicável o parágrafo único do art. 24 da Lei $\mathrm{n}^{\circ} 8.666 / 93$.

É o que, salvo melhor juízo, nos parece. 